\title{
Organic fertilization for optimizing dryland rice production
}

\author{
Gusmiatun $^{1}$, A.D Murtado ${ }^{2}$, Neni Marlina*3 \\ ${ }^{1}$ Departemen of Agrotecnology, Fakulty of Agriculture, Muhammadiyah Palembang University, Jl. \\ Jenderal Ahmad Yani 13 Ulu Palembang, Indonesia \\ ${ }^{2}$ Departemen of Food Science and Tecnology, Fakulty of Agriculture, Muhammadiyah Palembang \\ University, Jl. Jenderal Ahmad Yani 13 Ulu Palembang, Indonesia \\ ${ }^{3}$ Departemen of Agrotecnology, Fakulty of Agriculture, Palembang University, Jl Darmapala No 1A Bukit \\ Besar Palembang, Indonesia
}

*Corresponding author: marlina002@yahoo.com

\begin{abstract}
Abstact
Productivity of local upland rice varieties are usually low, making farmers refrain to cultivate upland rice. This resulted in the low contribution of upland rice in production. However, farmers are still planting upland varieties of rice because of their desirability and adaptation to the environment. Therefore, we always need to develop new varieties that have high production and flavors that suit the tastes of society. The key to increase production of variety is providing sufficient nutrients during the growing period. This study aims to accelerate the availability of nutrients of organic fertilizer for the production of new upland varieties with high productivity. The study carried out in two phases and three different locations. All stages of research was setup in the field using Grid Design Divided (split plot design). In the phase-1, we determined the dose, 5, 10, and 15 tons/ha of organic fertilizer, as well as the adaptability of new varieties (genotype JT-DR-G-416 and parental varieties Jati Luhur and Dayang Rindu). The results of phase-1 showed that best dose was 15 tons/ha. Then we proceeded to the phase-2, which aimed to determine the best management practice to provide organic fertilizers such as: $\mathrm{C} 1=$ organic fertilizer spread directly on planting plots, $\mathrm{C} 2=$ organic fertilizer spread over the terraced planting, then sprayed EM-4, C3 = composted organic fertilizer spread on the plots before planting. The variables measured for the study at phase- 1 and phase- 2 included plant height $(\mathrm{cm})$, number of productive tillers/hill, the number of grains/panicle, 1000 grain weight (g), percent grain hollow/panicle (\%), and grain yield per clump (g). The results showed that the new variety/genotype JT-DR-G-416 can adapt better than both parents at upland field conditions. The production of JT-DR-G-416 was increased by $7.75 \%$, when 15 tonnes/ha of organic fertilizers was applied. Application of composted organic fertilizer could increase production by $33.22 \%$, compared to without compost. Application of organic fertilizers followed by giving a solution of microorganisms (EM-4) could improve upland rice production by 30.56 to $32.06 \%$.
\end{abstract}

Keywords: Improving yield, organic fertilizer, upland rice.

\section{Introduction}

National food security can be achieved when food production has been reached to maxium in the region or province. South Sumatra is one of the provinces in Indonesia which has a National Food Barn Program. It can meet the needs of the population of area and there is even a surplus of more than 450,000 tons (CBS, 2010). In 2015, rice production was also increased by $15.73 \%$ compared to 2014 (CBS, 2016). The increasing amount of agricultural land converted into oil palm plantations, rubber, as well as settlements in recent years is causing threats to food security in South Sumatra. Therefore, efforts to take advantage of dry land as upland rice planting area expansion is an alternative that is expected to maintain food security. The is a vast dry land area in Sumatra $~ 385,407$ ha. It has been managed down reaching 52,679 ha, or about $13.7 \%$ of the available land area (BPTP South Sumatra, 2009). In addition to increasing cultivated area, improvement of key factors such as upland rice farming system, such as use of improved varieties, and the correct use of fertilizers are of great importance. Cultivation of new variety is the easiest technology adopted by farmers because they are inexpensive and very practical (Agency for Agricultural Research and Development, 2007). In Indonesia, the contribution of improved varieties to increase rice production can be demonstrated through the successful achievement of self-sufficiency in rice since 1984. During this period rice production could be more attributed to the increase in productivity compared to increase in harvested area. In periods, 1971-2006 the increase in productivity contributed about $56.1 \%$, whereas the increase in cultivated area and interaction both contributed $26.3 \%$ and $17.5 \%$, respectively (Sembiring, 2008). 
Although the contribution of improved varieties has been proven to increase production, but in reality the society in many regions, particularly South Sumatra, are still using local varieties of upland rice for cultivation. It is mainly for the reason of environmental adaptation and desirability of flavor/taste. Therefore, it is necessary to pay attention to the existence or development of new varieties, which suits taste of society. These efforts have been undertaken and genotypes such as JLDR-G-416 generated from the cross between parental varieties Jati Luhur with short lifespan and high production and Dayang Rindu with very favorable taste and aroma exclusively suit taste of community. Field trials have confirmed producing $\sim 4.0$ tonnes/ha of rice cultivars with 95-100 days growing period (Gusmiatun, 2015).

A variety can express its genetic potential in a suitable environment. Therefore, environment can contribute JT-DRG-416 genotype as potential new varieties that may generate a good yield when a suitable dosage of fertilizer is applied.

Fertilizer is the key to the increased production of crops on dry land because generally, the dry land has a low level of soil fertility. The recommended fertilizer is organic fertilizer because it can provide a complete nutrient of $N, P$, and $K$, as well as other essential elements such as $\mathrm{C}, \mathrm{Zn}, \mathrm{Cu}, \mathrm{Mo}, \mathrm{Ca}$, $\mathrm{Mg}$, and Si. Organic material in organic fertilizers are also useful for loosening the soil, improve soil structure, texture, porosity, aeration, and soil microorganisms. They also facilitate the growth of plant roots whereas soil can store more water (Pure Yuniawati, 2003). Wahyu (2015) reported that application of 20 tons/ha organic fertilizer in upland rice can produce up to 7 tons/ha yield.

The use of organic fertilizers usually requires high dose of application due to their slow releasing nature and the ability to provide nutrients gradually and indirectly to the plants. Therefore, soils fertilized with manure can provide reliable results in the next planting season. However, the organic fertilizers can be applied at least 7-10 days before planting (Soepardi, 1983).

Nutrients of organic fertilizers can be quickly available to plants when they become composted in advance and prior to use using microorganisms (Widowati et al., 2005). Meanwhile, the composting process takes a minimum of few months to be used as fertilizer. Therefore, there is a need to find more effective solution for the use of organic fertilizers for faster availability to plants.

This study also aimed to identify the best dose of organic fertilizer, also the effectiveness of fertilization of upland rice in different ways of composted organic fertilizer with addition of composting microorganisms.

\section{Results and discussion}

Phase-1 study showed that effect of organic fertilizer dose was highly significant to growth and production, except for 1000 grain weight. Likewise genotype/varieties significantly affected growth and production of plant (Table 1).

The results of the Phase 2 study showed that the growth and production was affected more by organic fertilizer, regardless of time of application. Neither organic fertilizer nor time of application (Table 2) influence the percentage of empty grains per panicle.

Plant height $(\mathrm{Cm})$

Plant height and size of plant are easily observed as an indicator of growth and as a parameter to measure environmental influences or treatment applied. However, it is strongly influenced by genetic factors. The results showed that all varieties tested produced higher plant height in accordance with the increasing dose of organic fertilizer. Dayang Rindu has high genetic potential than Jati Luhur. Therefore, nutrients of organic fertilizer can be absorbed by plants. Therefore, Dayang Rindu varieties showed optimal genetic potential to increase plant height.

In addition to nutrient content, the availability of adequate water during growth can affect the height of rice plants. Wetland can provide a water supply for the plant vegetative growth phase so that the rice plant can grow higher when compared to those grown in the dry land. Nonetheless, the soybean can grow well in dry lands as this plant shows high adaptability with environemnt, when planted in the dry land. Both in the upland field and rice paddies the Dayang Rindu varietiy reached $105.6 \mathrm{~cm}$ height (Fig 1).

Plants that were fertilized with composted organic manure produced 15 tonnes/ha. They showed growth compared to the fertilizer treatments that distributed directly into the ground without composting. After spreading fertilizers to the land and then spraying solution of EM-4 microorganisms, the growth of plants was almost the same as composted fertilizer. The genotype JTLDR-G-416 treated with composted organic fertilizer showed heighth of $104.36 \mathrm{~cm}$. However, application of compost, sprayed with solution of microorganisms, spread to land produced a height of 102.89 $\mathrm{cm}$ (Fig 2).

Apparently, composted organic fertilizer can contribute to nutrients $\mathrm{N}, \mathrm{P}$ and $\mathrm{K}$ faster making it widely available to the rice plants to grow well. According to to Widowati et al. (2005), composting can accelerate the decomposition process of organic matter thereby increasing the nutrient content of the material. Microorganism solution added to composting, in addition to accelerating the composting process, can also increase the diversity of soil microorganisms that can support plant growth if directly applied to the soil.

\section{Total productive tillers}

The number of tillers produced by a variety is an indicator of a healthy plant growth or illness (Makarim, 2005). In addition, environmental factors also play a role. Therefore, generally, rice grown on dry land produce a less number of tillers compared to paddy as a result of water factor under limited conditions for plant growth. Edi et al. (2015), reported that the number of panicle produced in rice cannot be maximized if crops suffer from lack of water. From the research results we can see that genotype JT-DR-G-416 planted in dryland produces an average number of productive tillers about 9-10 panicle, but if planted in the fields it can produce an average number of productive panicles of 13-14. The same thing happened in Jati Luhur and Dayang Rindu varieties (Fig 3).

In addition to water conditions, another environmental factor that can affect the number of tillers of rice plants is soil fertility. The increasingly lush environment of plants can increase the number of productive tillers/panicles much more because of nutrient requirements can be met. The number of panicles produced under composted manure provided in advance at a dose of 15 ton/ha was 12.26 tillers. In contrast, we observed that if the organic fertilizers be directly added into the soil before composting, then the number of tillers is only 6.4. If the organic fertilizer be 
sprayed with microorganisms then applied to the field, then the number of productive tillers produced is 10.28 .

Composted organic fertilizer can provide a fairly high $P$ element. $P$ element plays an important role in improving the working efficiency of chloroplast functions as an absorber of solar energy in the process of photosynthesis. The energy generated in the process of photosynthesis is very important for cell division to form a new seedling. Besides the elemental $\mathrm{P}$ also play an active role in transferring energy into the cell (Hakim et .al., 1986) (Fig 4).

\section{Total grain per panicle}

Growing environment affects the amount of grain produced on each rice panicle. In an environment with enough water and nutrients, the amount of grain produced is higher. Genotype JTLDR-G-416 planted in dry soil with 15 tonnes/ha organic fertilizers, produced similar number of grains per panicle such as Dayang Rindu (144-145) and Jati Luhur (148149). Whereas, if they grow in paddy fields, the number of grains in each panicle increased to 149-152 (Fig 5). The same thing happens if the organic fertilizers applied to rice plants has already composted (Fig 6).

According to Lakitan (1995), the average grain size for is less affected by environmental conditions, but the number of grains per individual plant can be influenced by the environment, the air temperature, the availability of water and nutrients.

\section{The weight of 1000 grains}

The results showed that there was no difference in the average weight of 1000 grain if planted on dry land and in the fields, i.e. $26-27 \mathrm{~g}$ (Fig 7). This shows that the environment in the drylands can provide nutrients and enough water during grain filling. At the time of the formation of seeds, plants need nutrients and water in sufficient quantities. 1000 grain weight will increase when the humidity of groundwater is maintained during the process of plant growth, but sufficient nutrients must also be available (Roesmarkam and Yuwono, 2002). Water serves as a transport result of photosynthesis and nutrients from cell to cell and from organ to organ (Andoko, 2005).

The results showed that if the environment can provide more nutrients, then the weight of 1000 grains of rice may also increase. Application of composted organic fertilizer increased the weight of 1000 grains up to 28.26 grams. However, no composted fertilizer, sprayed with microrganisms produced 1000 grains with weight of 27.75 grams. The direct application of manure without composting produced a 1000 grains weight of 26.69 grams (Fig 8).

The composted organic fertilizer had a low value of $\mathrm{C} / \mathrm{N}$ ratio. Then if it is used as fertilizer, can quickly improve the biological, physical, and chemistry of the soil, producing a better crop production.

\section{Percentage of empty grain}

The highest percentage of the empty grain of plants grown in dry land was $7.2 \%$, while for plants in paddy field was $6.3 \%$ (Fig 9). This illustrates that the source (source) was still able to assimilate into unsteady supply (to sink) so that they can produce a high percentage of filled grain (Murata and Matsushima, 1978).

Increase of nutrients in the soil where rice grows in dry soil do not significantly affect the amount of grain. In this study we evidenced that providing composted organic fertilizer in rice, does not significantly affect the number of empty grains compared to plants, fertilized with composted organic fertilizer where the numbe was 5.55 to $6.39 \%$ (Fig 10).

\section{Wet grain weight per panicle}

Heavy grain in each panicle is used as a variable that can picture crop yiled in a particular area. Heavy grain can also describe the ability of nutrient uptake by rice plants and also to save the results of photosynthesis in the form of grain.

We observed that the average weight of wet rice grain per panicle cultivated in paddy field was higher, compared to dry fields, where the production of JTLDR-G-416 genotype reached to $37.78 \%$. The averages of wet grain weight per panicle for genotype JTLDR-G-416 were $32.97 \mathrm{~g}$; Dayang Rindu $28.73 \mathrm{~g}$, and the weight of wet rice for Jati Luhur is $30.63 \mathrm{~g}$ (Fig 11).

Grain weight per hill affected the ability of plants to take advantage of environmental factors such as nutrients, water, carbon dioxide, temperature, and solar energy to perform photosynthesis. The differences in environmental factors affect carbohydrates, proteins, fats and other organic acids, which are produced from the photosynthetic process. They wil further affect the growth and productivity of plants, in this case, the grain formation.

Water serves as the transport of substances (the result of photosynthesis and nutrients) from cell to cell and from organ to organ. Water transfers the photosynthesis products from the phloem to sink organ. In rice grown in paddy fields, the water requirements to transfer and disseminate the photosynthesis products are met. Thus, the formation of grain will not have any problems, increasing number of nutrients that can be transported by water. Rice plants grown in composted organic manure will produce a number of productive tillers because the growth environment is able to provide the appropriate nutrients for plant growth, then for the growth and development of a number of productive tillers, leading to higher grain weight per plant. We observed that the weight of the grain in each cluster is greater (60.51

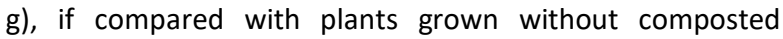
organic fertilizer $(40.55 \mathrm{~g})$, whereas not composted organic fertilizer sprayed with microorganisms after application produced the wet grain weight of $50.48 \mathrm{~g}$ per panicle. Organic fertilizers applied to rice crops in the dry land at the time one week before planting makes not much different effects on the growth and yield, when compared with organic fertilizer given during the two weeks before planting. The organic fertilizer that has been composted and not composted produced results such as following: the number of productive tillers $=8.36$; number of grains per panicle $=$ 236.55 grains; 1000 grains weight $=27.57 \mathrm{~g}$ in the paddy field. The amount of organic material that can be passed through the process of decomposition of fertilizers two weeks prior to planting was more, compared with fertilizer given during one week before planting. 
Table 1. Effect of dose Diversity Analysis of Organic Fertilizer and Varieties against Variables Observations.

\begin{tabular}{lllll}
\hline Variables measured & \multicolumn{2}{c}{ Treatment } & \multicolumn{3}{c}{ The coefficient of } \\
& $\mathrm{P}$ & $\mathrm{V}$ & $\mathrm{I}$ & \multicolumn{2}{c}{ variance (\%) } \\
\hline Plant height (cm) & $* *$ & $* *$ & $\mathrm{~ns}$ & 3.00 \\
The number of productive tillers (panicle) & $*$ & $\mathrm{~ns}$ & $\mathrm{~ns}$ & 22.68 \\
Number of grains per panicle (item) & $* *$ & $* *$ & $\mathrm{~ns}$ & 0.37 \\
The percentage of empty grain (\%) & $* *$ & $* *$ & $* *$ & 6.69 \\
1000 grain weight (g) & $\mathrm{ns}$ & $\mathrm{ns}$ & $\mathrm{ns}$ & 2.10 \\
Grain weight per panicle (g) & $* *$ & $* *$ & $*$ & 6.82 \\
\hline
\end{tabular}

ns $=$ no real effect; $*$ Significant **highly significant; $\mathrm{P}=$ the dose of organic fertilizer; $\mathrm{V}$ :varieties; I = interaction.

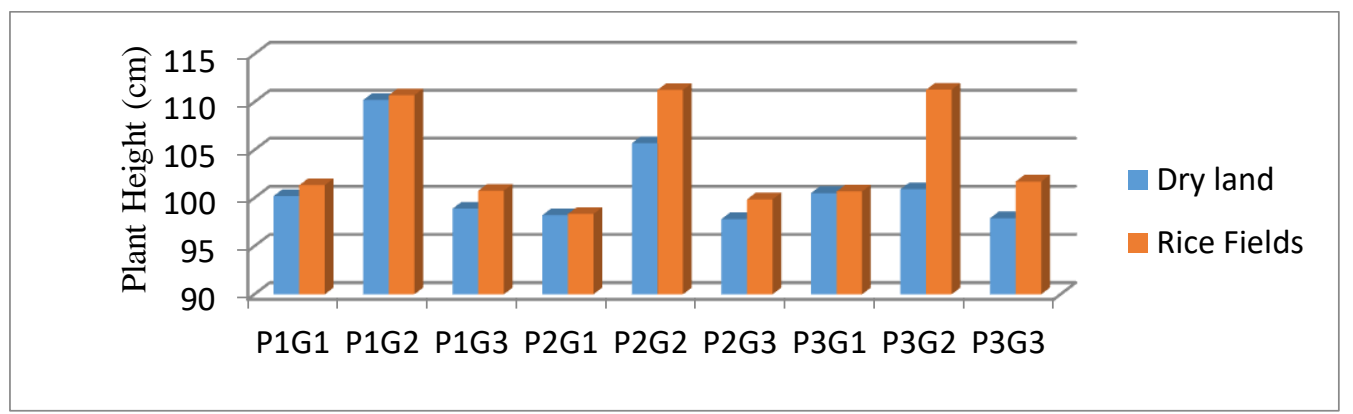

Fig 1. Genotypes of uppland rice grown on multiple levels of organic fertilizer in the wetland fields. P1G1 =5 tonnes / ha of organic fertilizer; genotype F1; P1G2 = 5 tonnes/ha of organic fertilizer; Genotype Dayang Rindu; P1G3 = 5 tonnes/ha of organic fertilizer; Genotype Jati Luhur; P2G1 = $10 \mathrm{t} /$ ha of organic fertilizer genotype JTLDR-G-416; P2G2 = $10 \mathrm{t} /$ ha of organic fertilizer genotype Dayang Rindu; P2G3 = $10 \mathrm{t} /$ ha of organic fertilizer genotype Jati Luhur; P3G1 = 15 tonnes / ha of organic fertilizer genotype F1; P3G2 = 15 tonnes/ha of organic fertilizer genotype Dayang Rindu; P3G3 = 15 tonnes/ha of organic fertilizer genotype Jati Luhur.

Table 2. Effect of time and diversity analysis and administration of organic fertilizer to variables.

\begin{tabular}{lllll}
\hline Variables measured & \multicolumn{3}{c}{ Treatment } & \multicolumn{1}{c}{$\begin{array}{c}\text { The coefficient of variance } \\
\text { (\%) }\end{array}$} \\
\cline { 2 - 4 } & $\mathrm{W}$ & $\mathrm{C}$ & $\mathrm{I}$ & 0.96 \\
Plant height $(\mathrm{cm})$ & $\mathrm{ns}$ & $* *$ & $\mathrm{~ns}$ & 2.31 \\
The number of productive tillers & $\mathrm{ns}$ & $* *$ & $\mathrm{~ns}$ & 0.34 \\
Number of grains per panicle (item) & $\mathrm{ns}$ & $* *$ & $\mathrm{~ns}$ & 13.77 \\
The percentage of empty grain (\%) & $\mathrm{ns}$ & $\mathrm{ns}$ & $\mathrm{ns}$ & 0.46 \\
1000 grain weight (g) & $\mathrm{ns}$ & $* *$ & $\mathrm{~ns}$ & 0.33 \\
Grain weight per panicle (g) & $\mathrm{ns}$ & $* *$ & $\mathrm{~ns}$ & \\
\hline
\end{tabular}

ns $=$ no real effect; $*$ Significant $* *$ highly significant; $P=$ the dose of organic fertilizer; $V$ :varieties; I = interaction.

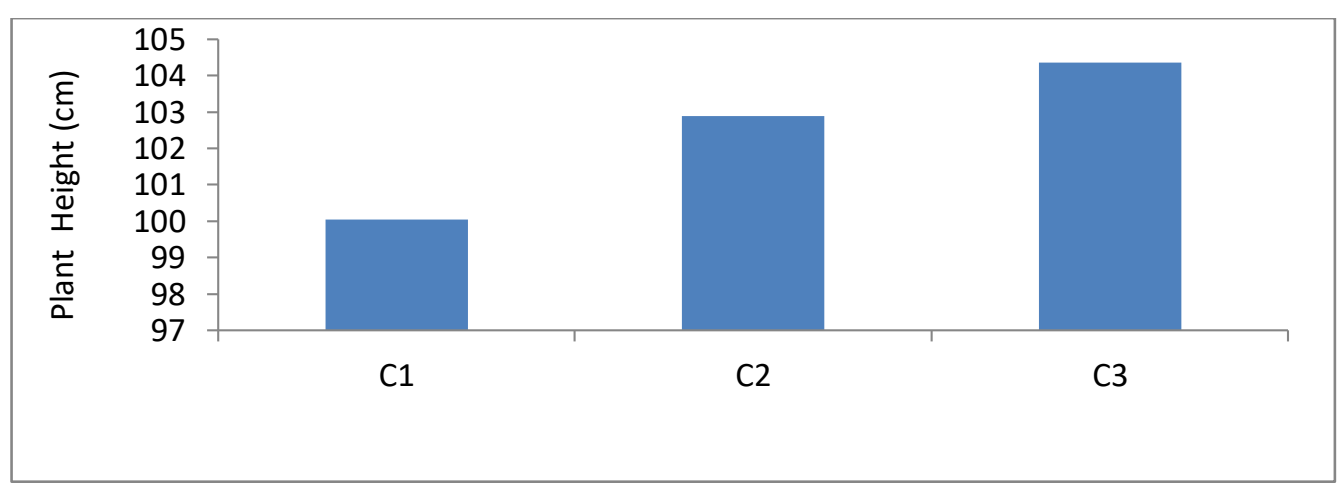

Fig 2. Height of genotype JTLDR G-416 using different organic fertilizer applications. Description: $\mathrm{C} 1=$ organic manure is spread directly, $\mathrm{C2}=$ organic manure is spread and + EM-4, C3 = organic fertilizer that has been composted. 


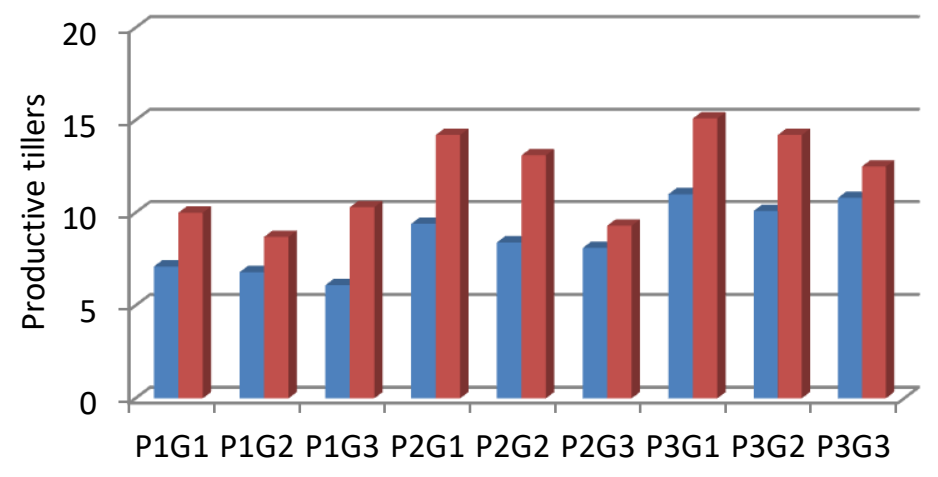

Dry Land

nice Fields

Fig 3. The number of productive tillers in levels of organic fertilizer (manure) in the fields and wetland. P1G1 = 5 tonnes / ha of organic fertilizer; genotype F1; P1G2 = 5 tonnes/ha of organic fertilizer; Genotype Dayang Rindu; P1G3 = 5 tonnes/ha of organic fertilizer; Genotype Jati Luhur; P2G1 = $10 \mathrm{t} /$ ha of organic fertilizer genotype JTLDR-G-416; P2G2 = $10 \mathrm{t} / \mathrm{ha}$ of organic fertilizer genotype Dayang Rindu; P2G3 = $10 \mathrm{t} / \mathrm{ha}$ of organic fertilizer genotype Jati Luhur; P3G1 = 15 tonnes / ha of organic fertilizer genotype F1; P3G2 = 15 tonnes/ha of organic fertilizer genotype Dayang Rindu; P3G3 = 15 tonnes/ha of organic fertilizer genotype Jati Luhur.

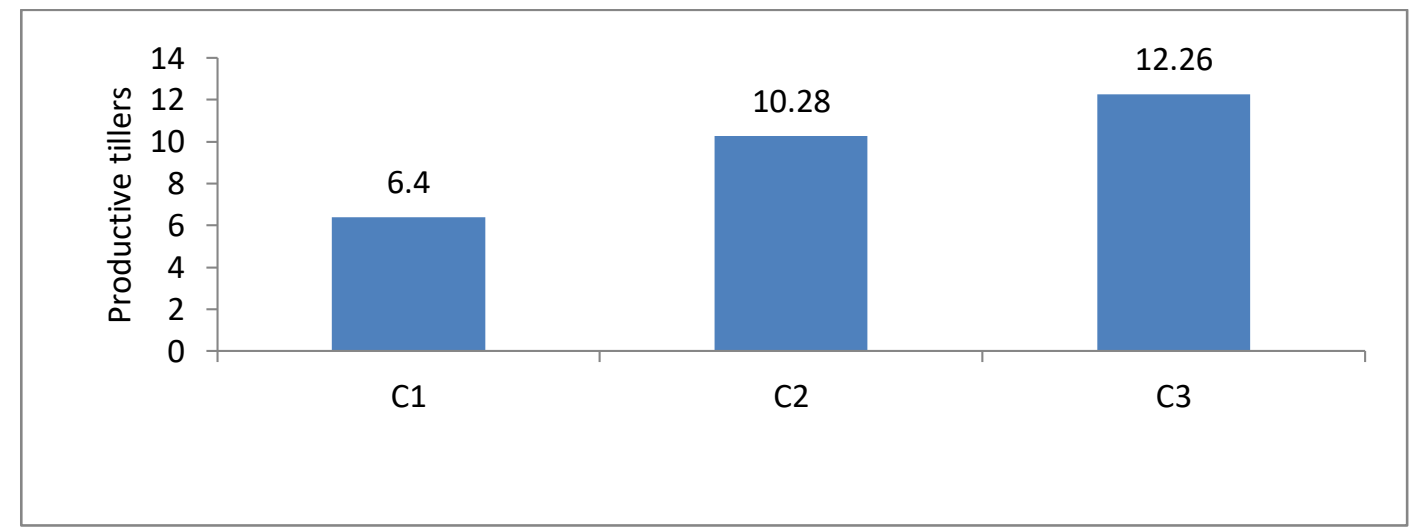

Fig 4. Total productive tillers of genotype JTLDR -G-416 using several manure application method. Description: $\mathrm{C} 1=$ manure is spread directly; $\mathrm{C2}$ = fertilizer chicken manure is spread and + EM-4; 33 = manure that has been composted.

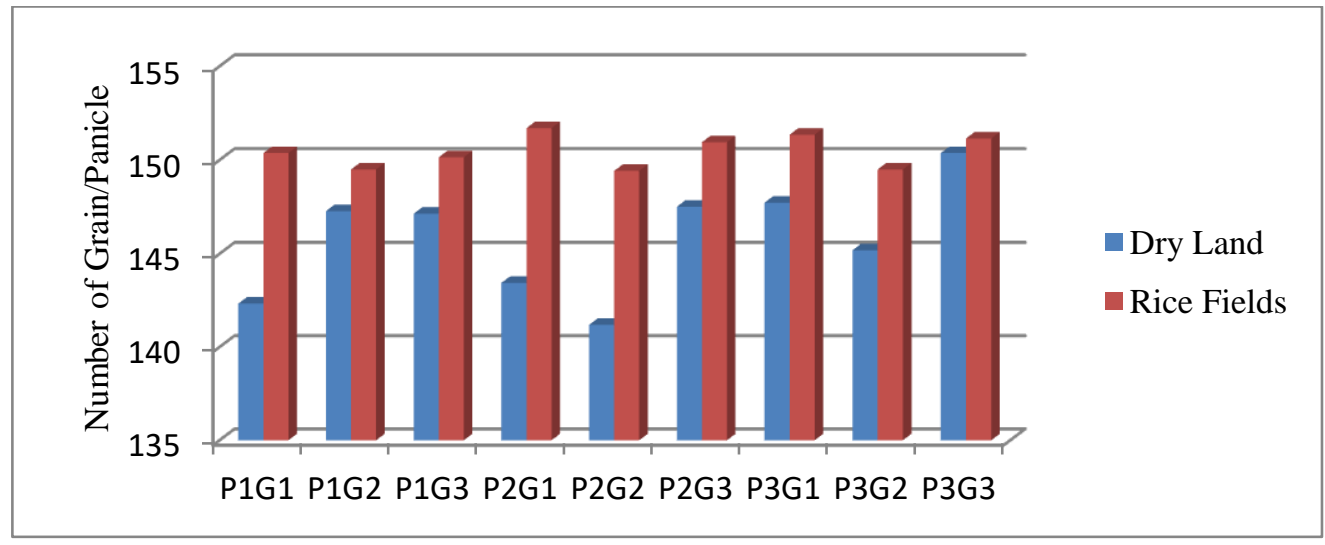

Fig 5. The number of grains per panicl under levels of organic manure in the fields and wetland. $\mathrm{P} 1 \mathrm{G} 1=5$ tonnes $/$ ha of organic fertilizer; genotype F1; P1G2 = 5 tonnes/ha of organic fertilizer; Genotype Dayang Rindu; P1G3 = 5 tonnes/ha of organic fertilizer; Genotype Jati Luhur; P2G1 = $10 \mathrm{t} /$ ha of organic fertilizer genotype JTLDR-G-416; P2G2 = $10 \mathrm{t} / \mathrm{ha}$ of organic fertilizer genotype Dayang Rindu; P2G3 = $10 \mathrm{t} / \mathrm{ha}$ of organic fertilizer genotype Jati Luhur; P3G1 = 15 tonnes / ha of organic fertilizer genotype F1; P3G2 = 15 tonnes/ha of organic fertilizer genotype Dayang Rindu; P3G3 = 15 tonnes/ha of organic fertilizer genotype Jati Luhur. 


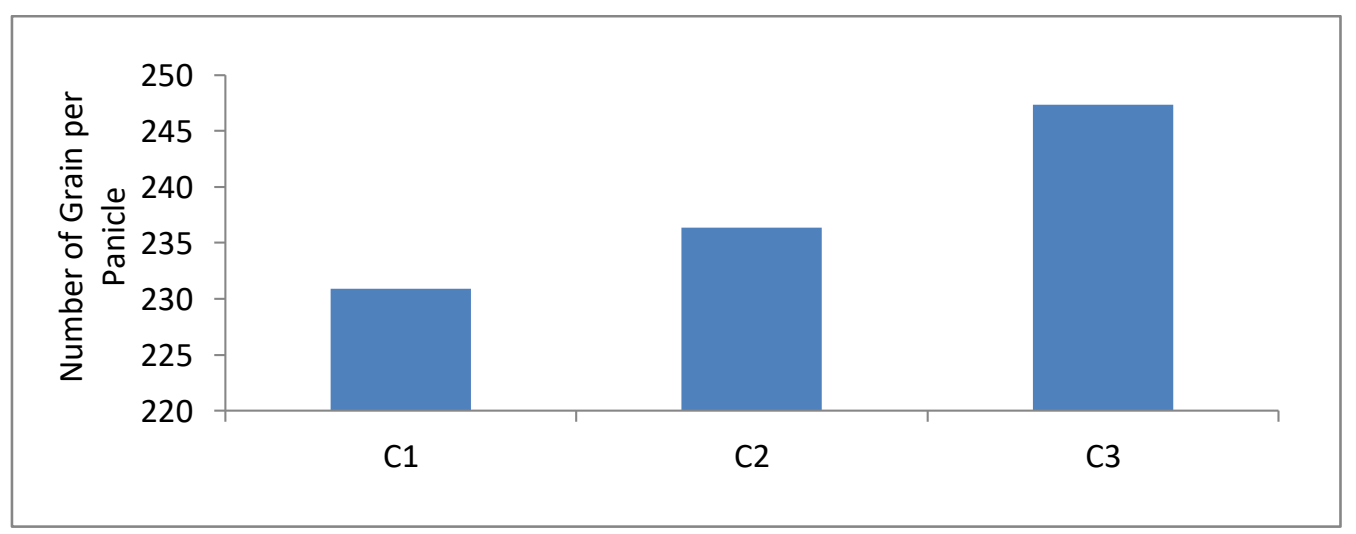

Fig 6. Total number of grain/panicles of genotype JTLDR -G-416 using several manure application method. $\mathrm{C} 1=$ manure is spread directly; $\mathrm{C2}=$ fertilizer chicken manure is spread and $+\mathrm{EM}-4 ; \mathrm{C} 3=$ manure that has been composted.

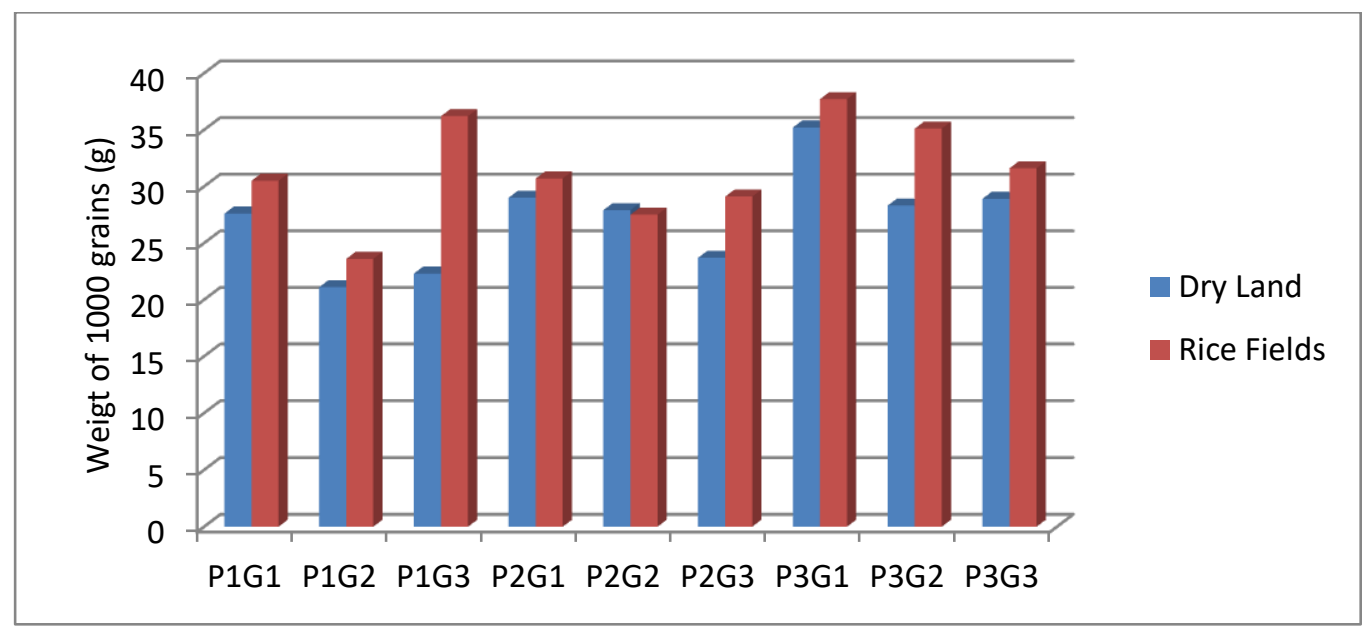

Fig 7. The weight of 1000 grains of upland rice genotypes in levels of manure in the fields and wetland. P1G1 = 5 tonnes / ha of organic fertilizer; genotype F1; P1G2 = 5 tonnes/ha of organic fertilizer; Genotype Dayang Rindu; P1G3 = 5 tonnes/ha of organ ic fertilizer; Genotype Jati Luhur; P2G1 = $10 \mathrm{t} /$ ha of organic fertilizer genotype JTLDR-G-416; P2G2 = $10 \mathrm{t} /$ ha of organic fertilizer genotype Dayang Rindu; P2G3 = $10 \mathrm{t} /$ ha of organic fertilizer genotype Jati Luhur; P3G1 = 15 tonnes / ha of organic fertilizer genotype F1; P3G2 = 15 tonnes/ha of organic fertilizer genotype Dayang Rindu; P3G3 = 15 tonnes/ha of organic fertilizer genotype Jati Luhur.

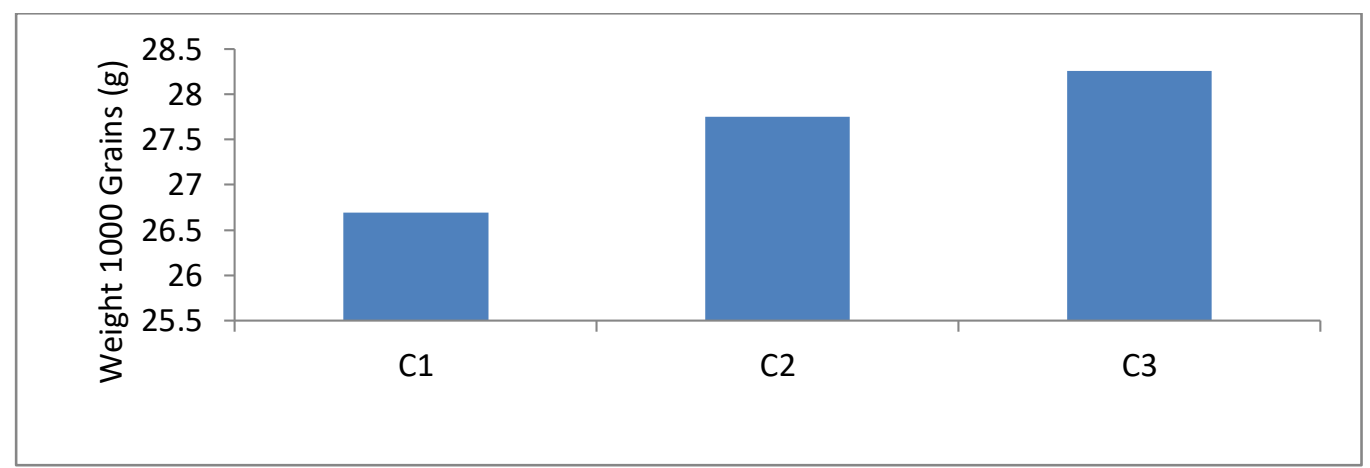

Fig 8. Weight of 1000 grains in genotypes JTLDR-G-416 using several manure application methods. $C 1=$ manure is spread directly $\mathrm{C} 2=$ fertilizer chicken manure is spread and $+\mathrm{EM}-4 ; \mathrm{C} 3=$ manure that has been composted. 


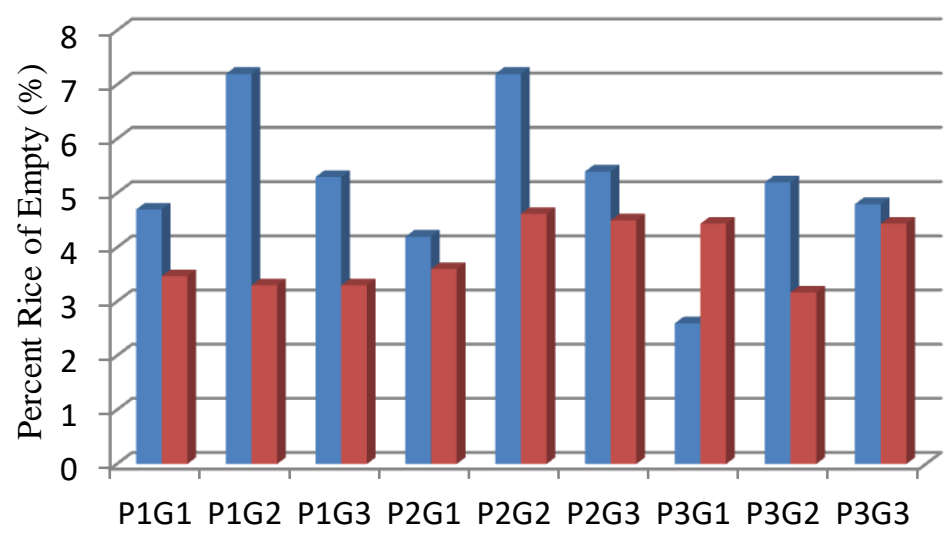

Dry Land

- Rice Fields

Fig 9. Percentage of empty grain in rice genotypes at different levels of manure in the fields and wetland.

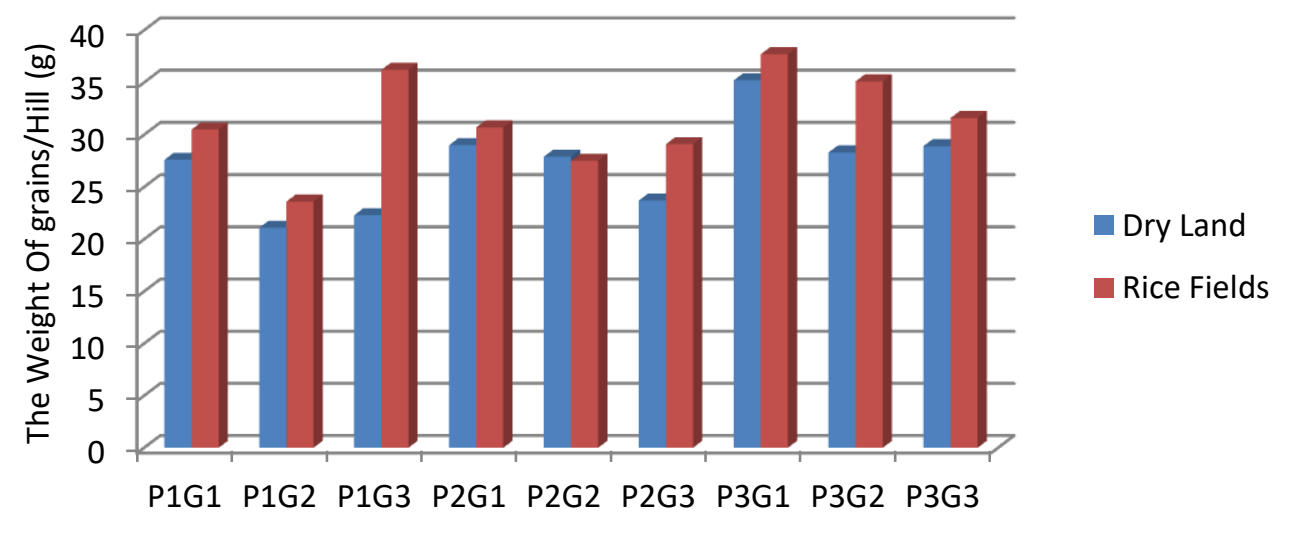

Fig 10. The weight of grain per hill of dryland rice genotype at several levels of organic fertilizer in dry land and rice fields.

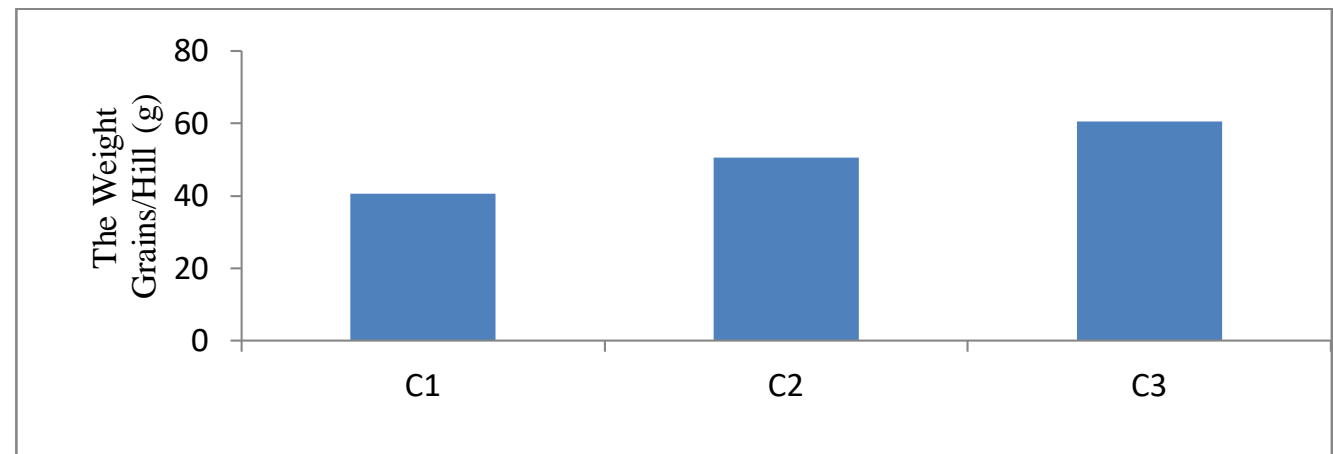

Fig 11. Grain weight per hill in genotype JTLDR-G-416 under various organic fertilizer application.

Decomposition of organic matter followed by an increase in population of organisms causes microorganisms phosphate bound in the soil. Furthermore, the results of decomposition in the form of organic acids effectively react with Fe and Al form a complex compound. Binding of Fe and Al can reduce the binding of P. Stevenson (1994), observed that the phosphate fixation can be decreased in the presence of organic matter, because organic acids produced from the decomposition of organic material can bind with $\mathrm{Fe}$ and $\mathrm{Al}$, so that $\mathrm{P}$ will be available for plant. Decomposition in the form of organic acids effectively react with $\mathrm{Fe}$ and $\mathrm{Al}$ and form a complex compound. Binding of Fe and Al can reduce the binding of $\mathrm{P}$.

\section{Materials and Methods}

\section{Phase-1 in paddy (wetland)}

The phase- 1 study conducted in dryland and paddy using some new varieties of upland rice seeds (genotype JTLDR-G416), Dayang Rindu, Jati Luhur, and organic fertilizer from chicken manure. The plots divided (Split-plot design) with 9 
treatment combinations and repeated 3 times. In the main plot dose of organic fertilizer $(P)$, namely: $P 1=5$ tonnes/ha, $\mathrm{P} 2$ = 10 tonnes/ha, and P3 = 15 tonnes/ha were used. For subplots the following varieties $(\mathrm{V})$ were used as follows: $\mathrm{V} 1$ = JTLDR-G-416, V2 = Dayang Rindu, V3 = Jati Luhur.

\section{Traits measured}

Variables consisted of: plant height $(\mathrm{cm})$, number of productive tillers/hill, the number of grains/panicle, 1000 grain weight $(\mathrm{g})$, percent grain vacuum (\%), and the fresh weight of grain/clump (g).

\section{Phase-2 in dry land}

The same methods was used as conducted in paddy filed using a split-plot design (split-plot design) with six combination of treatments, repeated 4 times. In the main plot is the time of giving the organic fertilizer (W) as follows: W1: given at 1 week before planting, W2: given at 2 weeks before planting. As a subplot we provided organic fertilizer (C) as following: C1 = spread directly onto fields, C2 = spread to land and then sprayed with liquid microorganisms, and C3 = composted before spreading to land.

\section{Traits measured}

Plant height $(\mathrm{cm})$, number of productive tillers/plant, the number of grains/panicle, 1000 grain weight $(\mathrm{g})$, percent empty grains (\%), and the fresh weight of grain/panicle(g).

\section{Conclusion}

The new variety JTLDRG-416 showed better adaptability and higher production than both of parental (Dayang Rindu and Jati Luhur), when grown in the fields. The organic fertilizer (manure) composted at a dose of 15 ton/ha, added one week before planting showed the best growth and production of the upland rice crop $(+67 \%)$, compared to applying manure immediately one week before planting.

\section{Aknowledgement}

I would like to thank Kmentrian Research, Technology, and Higher Education, which has funded this research.

\section{References}

Andoko A (2005) In Organic Rice Farming. Governmental spreader. Jakarta. $96 \mathrm{p}$.

Apriyantono A (2010) Prevent Food Crisis, Indonesia took 15 million $\mathrm{Ha}$ of Land Pertanian.http: //antonapriyantono.com/2007/08/06/cegah-krisispangan-indonesia-butuh-15-juta-ha-lahan-pertanian / [Accessed, September 30, 2010] p.

BPTP South Sumatra (2010) Agro-Ecological Zone Map of South Sumatra province. BPTP South Sumatra. Palembang. Central Bureau of Statistics. Banyuasin 2010. In Figures.

BAPELUH Kab. Musi Rawas. Description Rice Varieties (2012) Dayang Rindu. Heriawan.Musi Rawas.

Edi S, Novriati Midverizanti D (2015) Study of growth and potential results in some resistant upland local varieties of rice in drought stress. National Seminar 20152015 Land Suboptimal Palembang.

Gusmiatun (2015) Performance of agronomical characteristics of rainfed rice varieties at Ogan Ilir district, South Sumatra Province. International Journal of Engineering Research and Science \& Technology. 5(2):2735.

Judges N, Nyakpa MY, Lubis AM, Nugroho SG, Data MA, Hong GB, Barley HH (1986) Fundamentals of soil science., University of Lampung, Lampung.

IRRI (1996) Standard evaluation system for rice (SES). 4th ed. International Rice Research Institute, Los Banos, Philippines.,

IAARD (2007) The response of growth and yield of new varieties (VUB) rice.Badan Agricultural Research, Jakarta

Makarim, AK et al. 2005. "Optimization Component of Rice Varieties". Final report. Rice Research Books. 80 p.

Murata Y, Matsushima S (1978) "Rice" In Evans. LT (Ed.) Crop Physiology. Cambridge: University Press. Cambridge. P. 7399.

Sitompul BC, Guritno B (1995) Analysis of plant growth. Gadjah Mada University.

Soepardi G (1983) Nature and characteristics Tanah.Jurusan Soil Science. Faculty of Agriculture, IPB, Bogor.

Soemardi (2000) Morphology Sistemmatika and rice.http: //hirupbagja.blogspot .com / 2009/09 / morphology-plantpadi.html, Accessed on 03 April 2017.

Stevenson FJ (1994) Humus Chemistry, Genesis, Composition and Reaction. John Wiley and sons. New York.

Wahyu S (2008) Results of upland rice seeds from two different sources. Journal of Food Crops Research. Surakarta. 